\title{
GROWTH SCENARIOS OF ORGANIC AREA IN ROMANIA UNTIL 2025
}

\author{
Adrian BĂNEȘ, Romanian Academy - Timisoara Branch, 24 Bv. Mihai Viteazu, Timisoara, Timis County, Romania, \\ abanes@gmail.com (corresponding author) \\ Păun Ion OTIMAN, Romanian Academy - Timisoara Branch, 24 Bv. Mihai Viteazu, Timisoara, Timis County, Romania, \\ otiman@acad.ro \\ Tiberiu IANCU, Banat's University of agricultural Sciences and Veterinary Medicine "King Michael I" from Timisoara, 119 Calea \\ Aradului, Timisoara, Timis County, Romania, tibi_iancu@gmx.de \\ Manuela Dora ORBOI, Banat's University of agricultural Sciences and Veterinary Medicine "King Michael I" from Timisoara, \\ 119 Calea Aradului, Timisoara, Timis County, Romania, orboi@usab-tm.ro
}

Organic farming uses management practices that would avoid the use of chemical inputs and minimizes damage to the environment and wildlife. Thus we are brought significant restrictions on synthetic chemicals used in obtaining food products. The method involves different practices aimed at protecting the environment, maintaining and enhancing soil fertility, obtaining unpolluted and high quality agricultural products, and at last, promoting sustainable agricultural development. Romania has a great opportunity for organic farming as a result of natural conditions. However, Romania is located behind other EU or world countries. The present study shows the empirically based growth rate; of organic agriculture needed by Romania to reach in year 2025 the level of other countries. For comparison and calculations were considered France (one of the major players in the market of organic products) and Lithuania (that also has a well-developed organic agriculture). The results show that the current growth is not enough to overcome the first half of the top EU countries and requires an acceleration of this process of transformation into organic.

Keywords: organic agriculture, growth scenarios, Romania, forecast.

\section{INTRODUCTION}

In year 2007 it was approved Regulation no. 834 of the Council of Europe on organic production and labeling of organic products and repealing Regulation no. 2092/1991 (***, Regulation EC no. 834/2007, 2007). This Regulation lays down common objectives and principles underlying the rules it contains on all stages of production, in processing and distribution of organic products and their control and use in labeling and advertising of indications referring to organic production applied from 1 January 2009. The Regulation shall apply to the products of agricultural origin like live or unprocessed agricultural products, processed agricultural products for use as food, animal feed, seeds for cultivation, and include those from aquaculture when placed on the market or are intended to be placed on the market. The objectives, principles and rules applicable to organic production are contained in national legislation in this field in accordance with Community law (Stanciu, 2008; ***, Romanian Government Emergency Ordinance no.34/2000, 2000; ***, Regulation EC no. 834/2007, 2007, ***, http://eur-lex.europa.eu, 2015). These rules, along with defining the production method in the production plant, livestock and aquaculture regulates aspects of organic farming system from processing, labeling, trade and import, to inspection and certification of organic products.

In Romania there are great opportunities for organic farming as a result of natural conditions we have, for example a large area occupied by pastures and hayfields, the use of less chemical fertilizers, pesticides and herbicides than in other countries and a lower degree of pollution of soil and water in comparison with other countries (Sadgrove, 1998; Adamov, 2008; Iancu, 2011; Stoian, 2014). But still, we are among the worst in organic agriculture. Through this work we want to show the current trend of organic production in Romania and how it should look to get close to other EU countries. Our goal is to provide empirically based forecast, a profile on the growth needs of Romanian organic production. The stages through which this study is passing are to determine the regression relationships from existing values at this time for France and Romania, and after for Lithuania and then determining the regression relationship and trend for the next years until 2025, for the three countries. Finally, the results show the differences between this countries and the increase to be followed by Romania to achieve the values of other countries.

Copyright (C) 2015 The Authors. Published by Aleksandras Stulginskis University. This is an open-access article distributed under the terms of the Creative Commons Attribution License (CC-BY 4.0), which permits unrestricted use, distribution, and reproduction in any medium, provided the original author and source are credited. 


\section{RESEARCH METHODS}

In the present study we took into account statistics on organic production, especially those related to France, Lithuania and Romania. We considered France as the reference country for Romania, because there were many similarities in the time between the two countries and because it is one of the countries involved in particular in the production and marketing of organic products. Also, from our studies, Lithuania has a great involvement in organic agriculture.

We realized a survey of the current situation, calculating the growth rate required to be conducted by Romania, in 2025 to achieve the current level of France (Otiman, 2015).

France has an area of $549970 \mathrm{sq} \mathrm{km}$, divided in agricultural land: $52.7 \%$, arable land $33.4 \%$; permanent crops $1.8 \%$; permanent pasture $17.5 \%$, forest: $29.2 \%$, other: $18.1 \%$. Romania has an area of 229891 sq km, divided in agricultural land: $60.7 \%$, arable land $39.1 \%$; permanent crops $1.9 \%$; permanent pasture $19.7 \%$, forest: $28.7 \%$, other: $10.6 \%$. Surfaces of the two countries differ, so we applied a coefficient of 2.39 for the values that were calculated. Lithuania has an area of $62680 \mathrm{sq} \mathrm{km}$, so we applied a coefficient of 0.27 for the values that were calculated for Romania.

Unfortunately, statistics on organic production lacking in most cases before 2006 or often the sources are contradicting. Also, the majority of statistical yearbooks provide data for at least 2 years old. Because of this, we relied on existing data from all three considered countries, on this basis going further for determining the regression relationship. Based on statistical methods, we considered that getting a close enough 1.00 correlation coefficient, shows that the relationship can be considered in forecasting calculations.

\section{RESEARCH RESULTS}

The first correlation we did for France and Romania, following that, in the next, to introduce data about Lithuania. Existing data from the years 2006-2012, shows a clear difference between the values of France and Romania, as well as increasing trend from one year to another, in both cases. In seven years, the increase was about $70 \%$ for France and about $50 \%$ for Romania (Table 1). The regression equation for the increase of total organic area converted was established as 2nd degree polynomial function, the correlation coefficient was 0.98 in the first case, namely 0.79 in the second, which is high enough to be close to reality.

Table 1. Certified organic crop area by crops products, fully converted crop area - Total crops (ha)

\begin{tabular}{|l|c|c|}
\hline Year/Country & France & Romania \\
\hline 2006 & 499589 & 65111 \\
\hline 2007 & 497314 & 74590 \\
\hline 2008 & 502234 & 83862 \\
\hline 2009 & 525638 & 82981 \\
\hline 2010 & 571815 & 96606 \\
\hline 2011 & 701111 & 103093 \\
\hline 2012 & 855642 & \\
\hline
\end{tabular}

Source: ***, Certified organic crop area by crops products, 2015; Willer, Helga and Julia Lernoud (Eds.), 2015

Having a clear upward trend (Table 1, Fig. 1) we stayed at the 2nd degree equation in conjunction with the high value of the correlation coefficient (over 0.75 for Romania and over 0.98 for France) we considered unnecessary a determinations by higher degree equations.

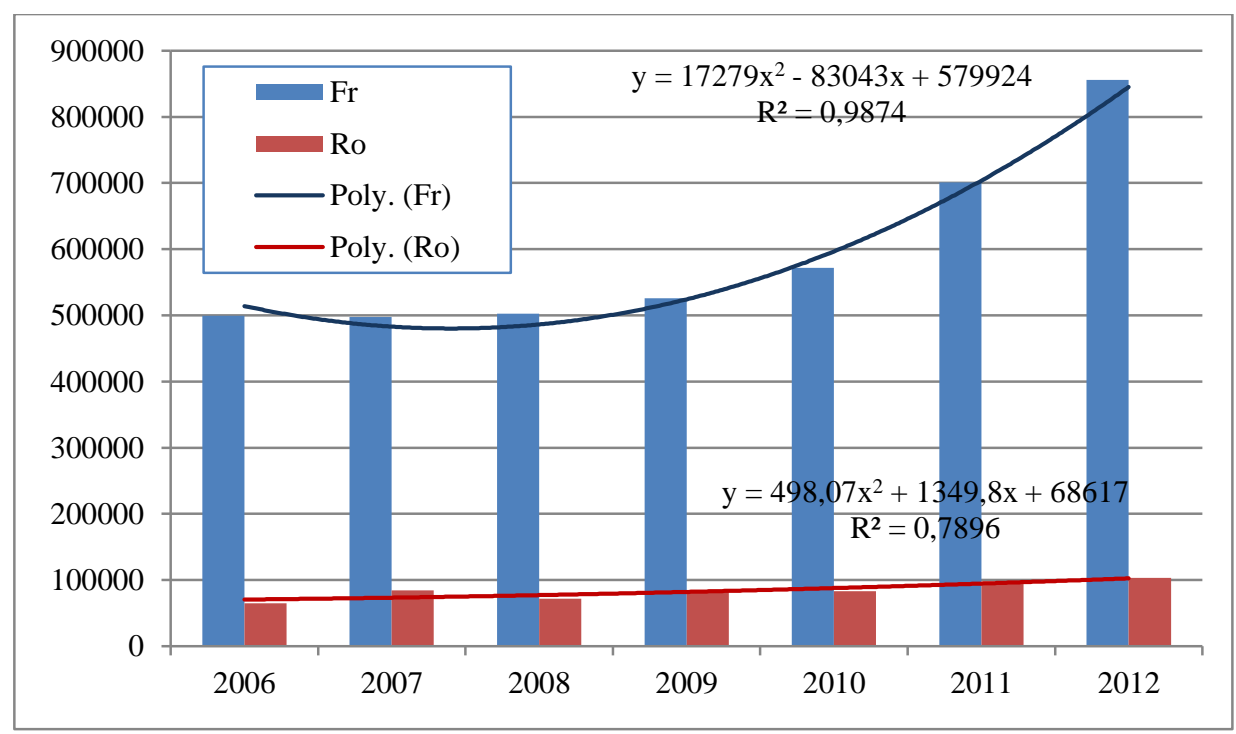

Figure 1. Fully converted total crops area in France and Romania, (ha) 
Following the obtained results, we made two forecasts, one for an extension of current growth and the other for an increase that brings Romania in year 2025 to the current level of France.

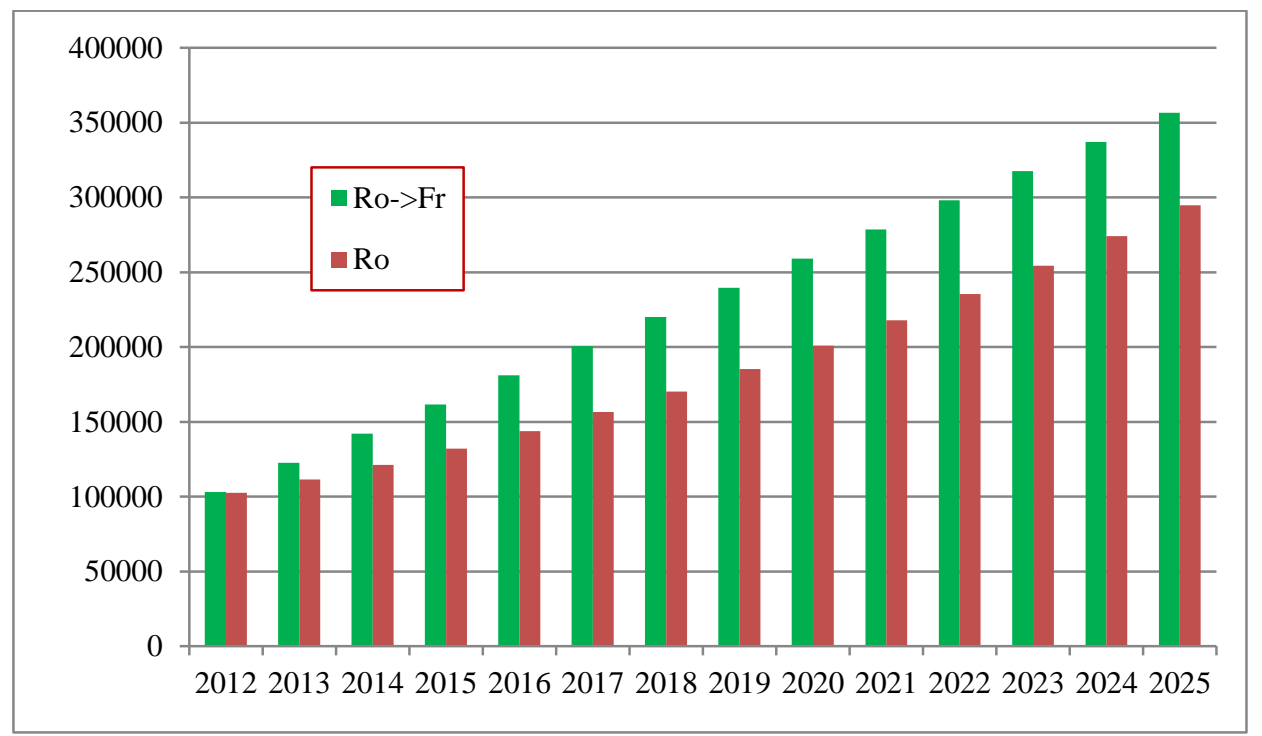

Figure 2. Forecasts, red - current growth, green - increase to achieve France level, ha

From the previous representations (Fig. 1, Fig. 2), it can be seen that there is a difference between actual growth trend and the need to reach levels close to those of France, Romania's annual growth should be higher with values between 5,000 and 10,000 ha annually.

Regarding the utilized agricultural area, share of total organic crop area out of total, the statistical data are presented in the table below. As we stated above, relevant data were found in the period 2006-2012, but were enough to get a high correlation coefficient around 0.9, even for a first-degree equation (Fig. 3).

Table 2. Share of total organic crop area out of total, utilized agricultural area, (\%)

\begin{tabular}{|l|c|c|c|c|c|c|c|}
\hline Country/Year & 2006 & 2007 & 2008 & 2009 & 2010 & 2011 & 2012 \\
\hline France & 1,7 & 1,9 & 2 & 1,9 & 2,9 & 3,4 & 3,6 \\
\hline Lithuania & 3,5 & 4,5 & 4,6 & 4,8 & 5,2 & 5,4 & 5,5 \\
\hline Romania & 0,8 & 1 & 1 & 1,2 & 1,3 & 1,6 & 2,1 \\
\hline
\end{tabular}

Source: ***, Certified organic crop area by crops products, 2015, Willer, Helga and Julia Lernoud (Eds.), 2015

This time we introduced in calculations Lithuania, in addition to France and Romania. For the three countries considered, we took data on the percentage of organic crop area from total agricultural area, because it offers a picture of proportions between the two areas. To simplify the calculations, as we said, we opted for linear equations, resulting that correlation coefficients were above 0.86 in all three cases, so the estimation is correct.

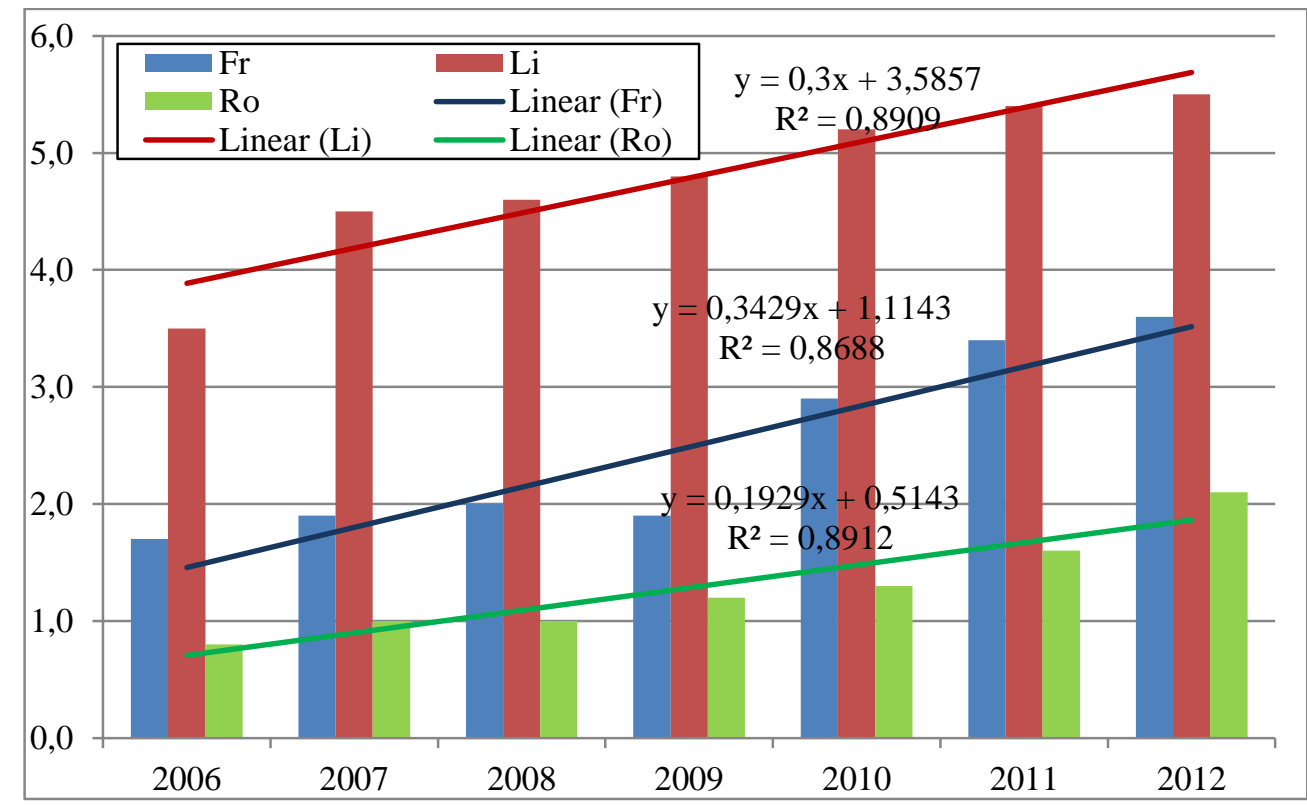

Figure 3. Share of total organic crop area out of total, utilized agricultural area, 2006-2012, (\%) 
In this chapter difference from France was not significant, Romania stands well, so we calculated the forecast for 2025 only from the current situation of Lithuania (Fig. 4, 5 and 6). As in the previous cases, we went on two forecasts, the current growth and that of achieving current values corresponding Lithuania.

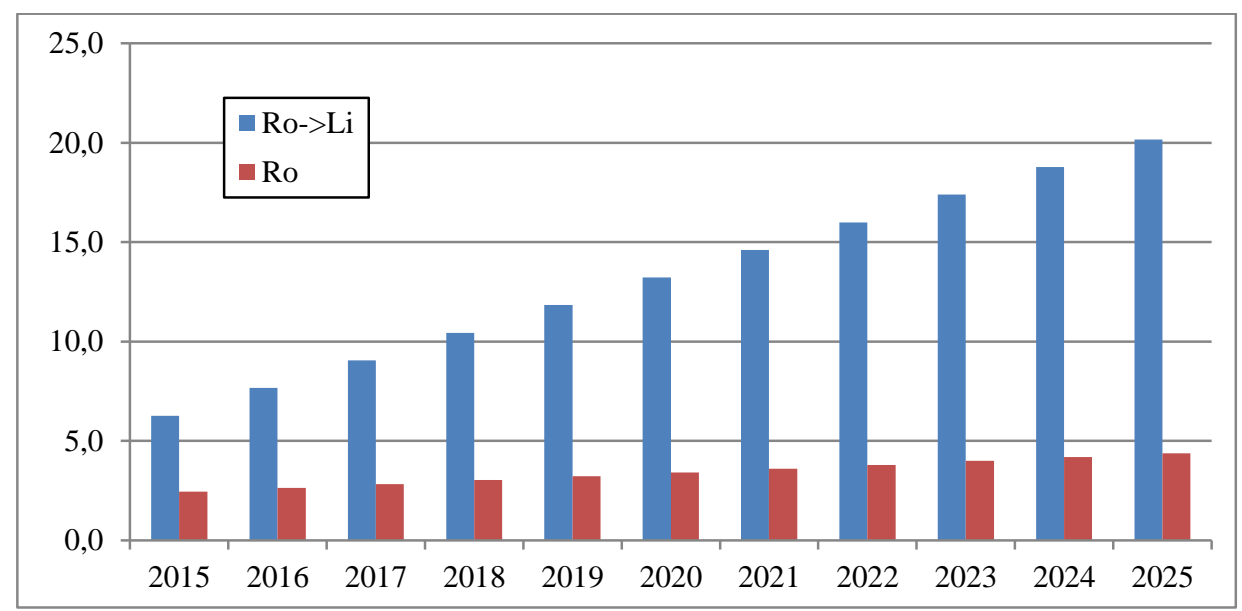

Figure 4. Forecasts, red - current growth, blue - increase to achieve Lithuania 2012 level, \%

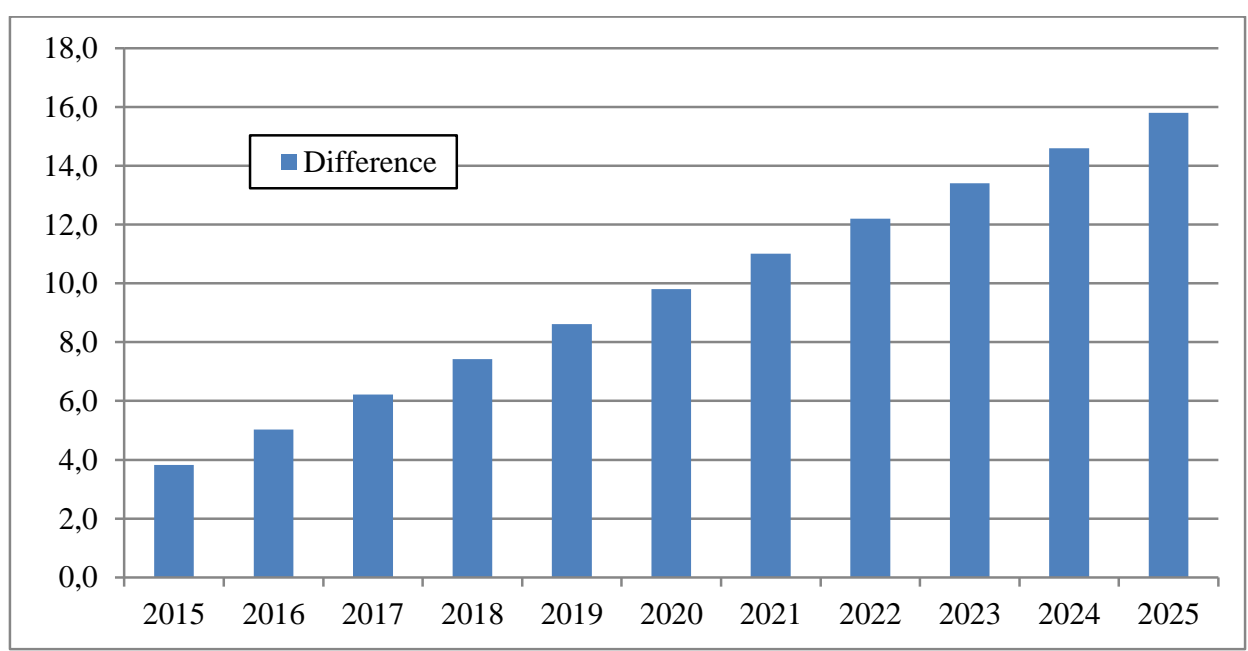

Figure 5. Differences between the two forecasts, $\%$

It can be seen that the difference in 2025 compared to the current level of growth is over $15 \%$, achieving it meaning an increase by an annual rate of only $1 \%$, which is not very much.

The latest forecast took into account the number of certified registered organic operators processing products issued from organic farming, respectively meat and production of meat products, processing and preserving of fruit and vegetables and manufacture of bakery and farinaceous products.

Table 3. Registered operators at the end of the year, processing and preserving of meat and production of meat products (number)

\begin{tabular}{|l|c|c|c|c|}
\hline Country/Year & 2010 & 2011 & 2012 & 2013 \\
\hline France & 575 & 550 & 614 & 599 \\
\hline Lithuania & 3 & 3 & 3 & 3 \\
\hline Romania & 3 & 2 & 1 & 1 \\
\hline
\end{tabular}

Source: ***, epp.eurostat.ec.europa.eu, Number of certified registered organic operators processing products issued from organic farming, 2015

Given the countries areas, as explained in method, the equivalent number of producers should be taking 250 for France as standard, respectively 11 for Lithuania as standard. The mathematical equations for the two estimates growth will be: $y=249(x-1) / 12+1$ (for France), and $y=10(x-1) / 12+1$ (for Lithuania). 


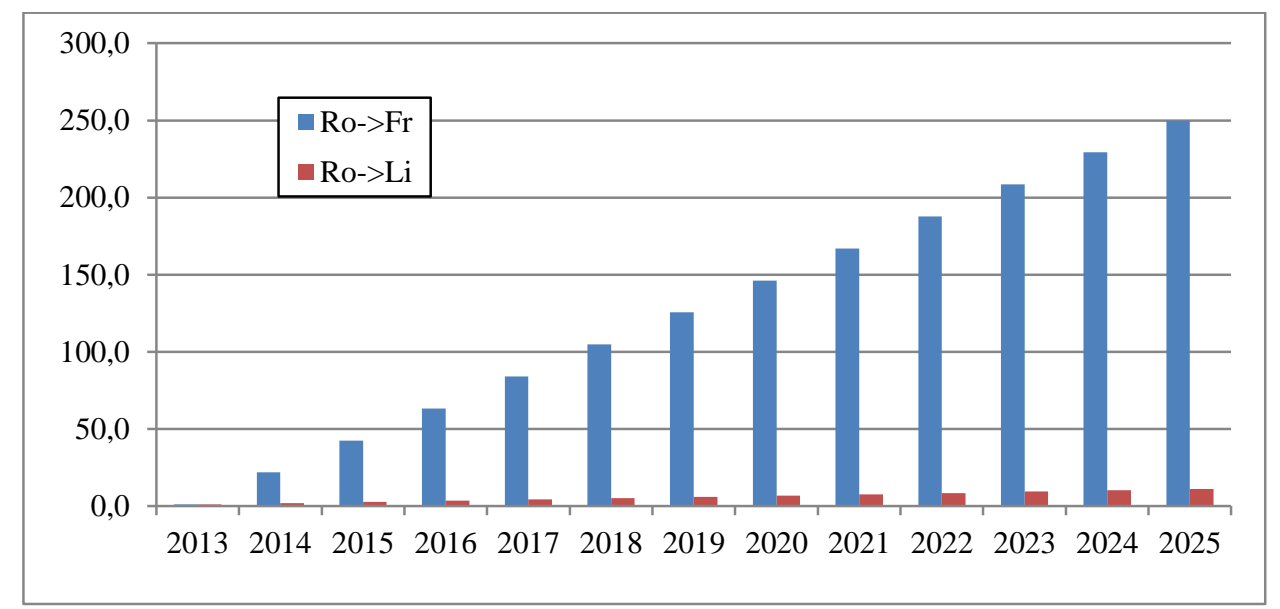

Figure 6. Forecasts for operators processing and preserving of meat and production of meat products, increase to achieve France (blue) or Lithuania (red) 2013 level in 2025

For processing and preserving of fruit and vegetables and manufacture of bakery and farinaceous products, the equations are similar, differing only by the target to be reached by Romania. In the first case we have 211 for France and 37 for Lithuania and in the second case a very high value to France, 2224 and a value of 18 for Lithuania, as seen in Fig. 7,8 and 9.

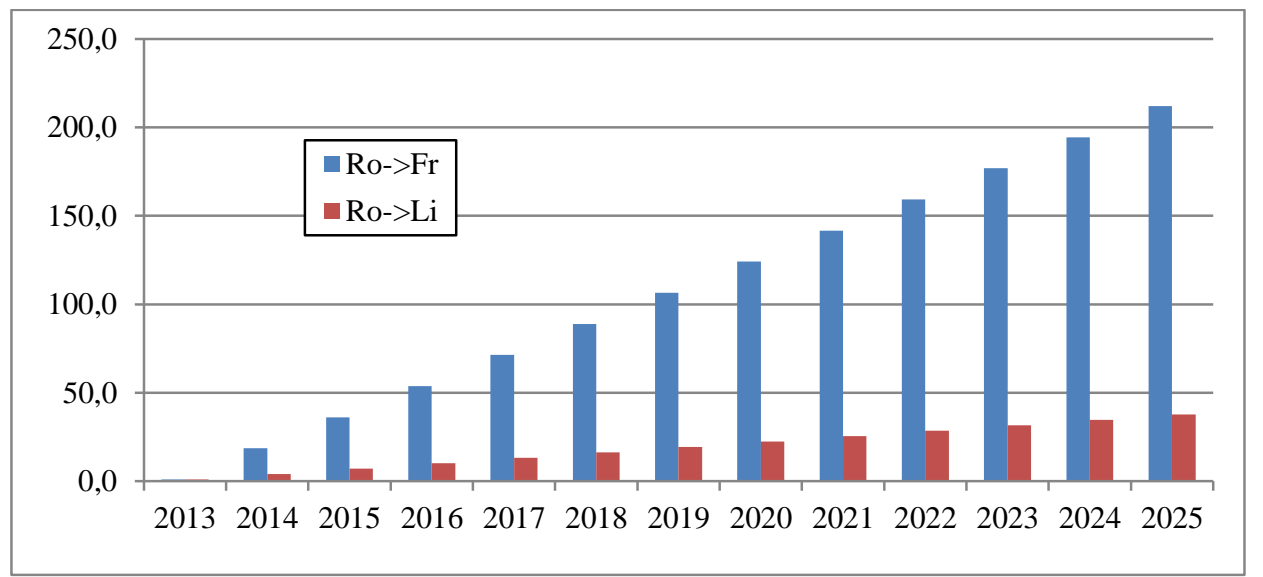

Figure 7. Forecasts for operators processing and preserving of fruit and vegetables, increase to achieve France (blue) or Lithuania (red) 2013 level in 2025

Regarding the forecasts for operators processing and preserving of fruit and vegetables, reaching a level close to that of Lithuania, means an annual increase of 3-4 operators compared to the current trend, and to achieve the level of France, an annual increase of over 15 operators. Given the variety and widespread of vegetable crops and orchards in Romania, this increase is easily achievable in future years, it only need that to move the processors more towards domestic production.

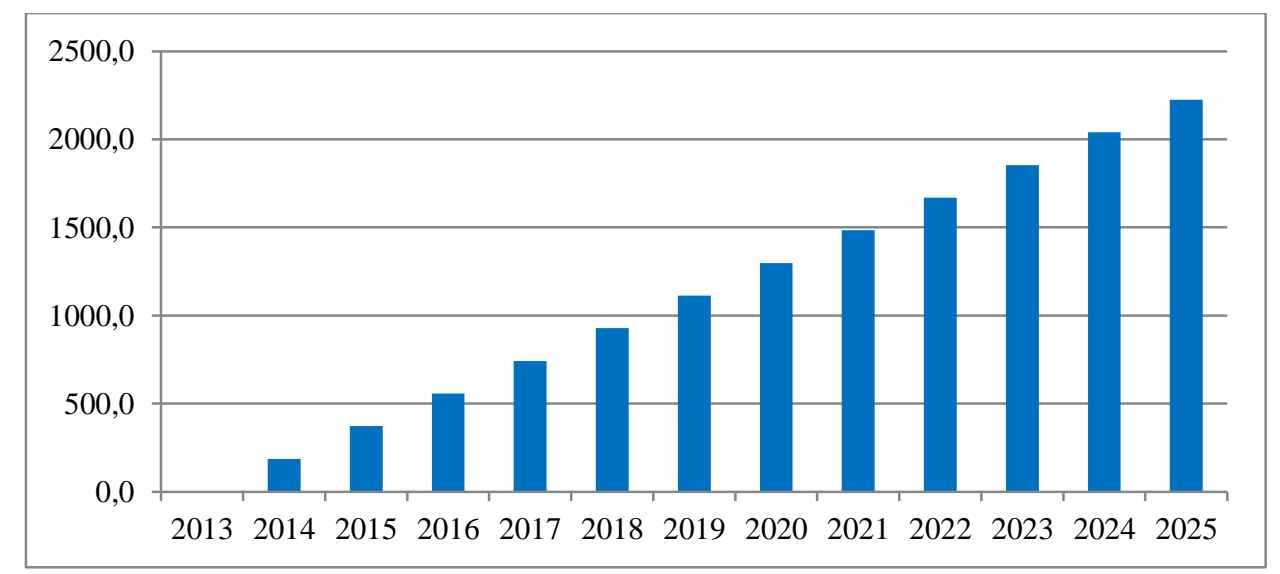

Figure 8. Forecasts for operators manufacture of bakery and farinaceous products, increase to achieve France 2013 level in 2025 
Regarding the forecasts for operators' manufacture of bakery and farinaceous products, the differences are higher than the previous to achieve France level (a country with strong traditions and great experience in bakery), over 175 operators annually, and slightly smaller to achieve Lithuania level, over 1.5 operators annually. Obtaining increases close to the analyzed countries seem more achievable if Romania follows Lithuania, the values of the latter being not very hard to reach.

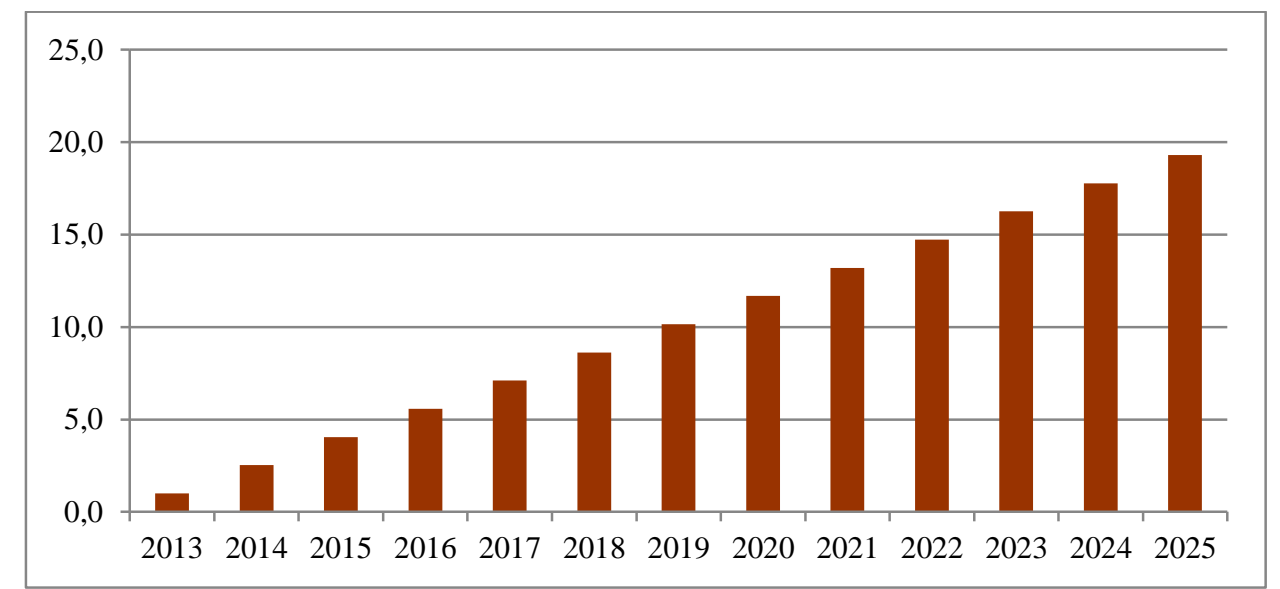

Figure 9. Forecasts for operators manufacture of bakery and farinaceous products, increase to achieve Lithuania 2013 level in 2025

An increase in growth would be welcome, especially considering that the amounts to be reached are, in both cases, the Lithuania and France values from 2013.

\section{CONCLUSIONS AND DISCUSSION}

According to the above, what to do next is quite clear. If it continues the current evolution, it takes about 20 years just to get to the actual values of other EU countries. So, Romania needs to accelerate the conversion of crops and other products in organic, because the current growth is not enough. In our opinion 10 years is considered to be a reasonable period, given the time needed to switch from a normal to an organic agriculture, 2 or 3 years, depending on the crops. However, to achieve certain values, such as the example of France in the last case, where forecasts were represented separately because of the enormous difference, seems quite unlikely. In addition, it must be considered that all countries involved in organic agriculture and organic products will not stand still, waiting to be reached, but most likely they will continue their growth. Without support from everyone involved, especially through adequate legislation, this goal will not be reached, and growth "on their own" will likely follow the current trend. Under the new common agricultural policy in 2015, EU Member States must use $30 \%$ of direct payments to farmers in order to carry out financing of sustainable agricultural practices. Moreover, Member States can provide additional support to farmers and operators in organic production through a various opportunities such as cooperation in the food chain to boost innovation, development of quality systems for agricultural products, groups or producer organizations etc. This support would be helpful to be increased, especially during conversion period, at the moment he has values between 1500 and 3500 euro / organic holding, depending on its size. Farmers cannot rely only on aid granted by the EU or by projects, which often they do not know how to write or where to submit them, as they also cannot rely on the government provides, which are arriving in most cases late and difficult to obtain. Also, consumers of organic products need to be informed and educated, to open more the present market to these products.

\section{REFERENCES}

1. Adamov, T. C., Iancu, M., Iancu T., Brad I. 2008. The organic agriculture - a way to protect the environment. Zootechnics and Biotechnology, Vol. 41, Iss. 1, ISSN 1221-5287, Agroprint, Timisoara.

2. Iancu, T., Brad, I., Milin, A., Hurmuzache, T. C., Iosim I. 2011. Aspects that characterize the quality of life in Romanian rural area, The $54^{\text {th }}$ International Scientific conference Durable Agriculture Development Strategies, USAMV Iasi, Scientific papers Agronomy series, Vol. 54(S), pp. 134-137, ISSN 1454-7414.

3. Orboi Manuela-Dora, Băneș A., Tiberiu I., Gherman R. 2015. 15th International multidisciplinary scientific geoconference, Vol. 3, ISBN 978-619-7105-41-4, pp. 67-82, Stef92 Technology Ltd., Bulgaria.

4. Otiman, P. I., Rujescu C. 2015. Forecast models of production and agri-food consumption in Romania - Horizon 2035, Timis Academic Days Symposium XVI edition, Timisoara.

5. Sadgrove, K. 1998. Ecological Guide Managers, Technical Publishing House, Bucharest.

6. Stanciu, S., Snooze, C. C. 2008. Integrating Environment into Agriculture and Forestry, Scientific Works, Vol. 51, Agronomy Series, ISSN 1454-7414, Banat's University of agricultural Sciences and Veterinary Medicine "King Michael I" from Timisoara.

7. Stoian, M. 2014. Ecomarketing, digital course, Academy of Economic Studies, http://www.biblioteca-digitala.ase.ro/biblioteca/carte2. asp?id=171\&idb=22 
8. Willer, H., Julia, L. (Eds.) 2015. The World of Organic Agriculture. Statistics and Emerging, Trends 2015. FiBL-IFOAM Report, 2015.

9. ***, Romanian Government Emergency Ordinance no.34 / 2000 on organic food products, approved by Law no. 38/2001, as amended and supplemented, 2001

10. ***, Regulation EC no. 834/2007 of 28th June 2007 on organic production and labeling of organic products and repealing Regulation EEC No. 2.092 / 91, 2007

11. ***, Certified organic crop area by crops products, 2015, http://ec.europa.eu/eurostat/web/products-datasets/-/food_in_porg1

12. ***, Number of certified registered organic operators processing products issued from organic farming, 2015, http://ec.europa.eu/eurostat/web/products-datasets/-/food_act3, 2015.

13. ***, http://eur-lex.europa.eu/legal-content/RO/TXT/?qid=1447064995681\&uri=CELEX:32007R0834, 2015. 